\title{
O ensino jesuítico no período colonial brasileiro: algumas discussões
}

\section{Discussions on Jesuit teaching in Brazil during the colonial period}

\author{
Alexandre Shigunov Neto* \\ Lizete Shizue Bomura Maciel ${ }^{* *}$
}

\begin{abstract}
RESUMO
O presente artigo pretende realizar uma análise do ensino jesuítico implementado no período colonial brasileiro e demonstrar que a estrutura escolar fundada pelos padres jesuítas no Brasil era adequada para o momento histórico vivenciado, levando-se em consideração quatro aspectos: os objetivos do Projeto Português para o Brasil; o projeto educacional Jesuítico; a própria estrutura social brasileira da época; e o modelo de homem necessário para a época Colonial. Os jesuítas, com seu Projeto Educacional, e os portugueses que vieram para a colônia brasileira em busca de riquezas, tiveram papel fundamental na formação da estrutura social, administrativa e produtiva da sociedade que estava sendo formada. Partindo do pressuposto de que o fenômeno educacional não é um fenômeno independente e autônomo da realidade social de determinado momento histórico, devemos analisar o projeto jesuítico levando-se em conta o desenvolvimento social e produtivo da época colonial. Assim, pode-se supor que o modelo educacional proposto pelos jesuítas, que pretendia formar um modelo de homem, baseado nos princípios escolásticos, era coerente com as necessidades e aspirações de uma sociedade em formação na primeira fase do período colonial brasileiro.

Palavras-chave: jesuítas, ensino jesuítico, Colônia.
\end{abstract}

* Administrador formado pela Universidade Estadual de Maringá (UEM). Especialista em Economia Empresarial pela Universidade Estadual de Londrina. Mestre em Educação pelo Programa de Pós-Graduação em Educação da UEM. Especialista em Economia Empresarial pela Universidade Estadual de Londrina. Doutorando do Programa de Pós-Graduação em Engenharia e Gestão do Conhecimento (EGC) da Universidade Federal de Santa Catarina (UFSC). Diretor de Pesquisa e Extensão da Faculdade Central de Cristalina (FACEC).

** Professora do Programa de Pós-Graduação em Educação da Universidade Estadual de Maringá (UEM). 


\begin{abstract}
Jesuit teaching in Brazil during the colonial period is analyzed. It may even be proved that the schooling structure established by the Jesuit fathers was extremely adequate for that specific historical period. Four aspects may be taken into account: the aims of the Portuguese Project for Brazil; the Jesuit Educational Project; the Brazilian social structure at that time; and the human model needed for the colonial period. The Jesuits' Educational Project and the Portuguese colonizers that came to the colony in search of wealth have an important role in the formation of the social, administrative and productive structure of a society in constant evolution. Since the educational phenomenon cannot be analyzed regardless of the social reality of a specific historical moment, the Jesuit's project has to be seen when the social and productive development during the colonial period is taken into account. The Jesuits' educational model that aimed at producing a human standard based on Scholastic principles was coherent with the needs and the expectations of an evolutionary society during the first phase of Brazilian colonial history.
\end{abstract}

Key words: jesuits, jesuit teaching, colony.

\title{
Considerações iniciais
}

O presente artigo pretende realizar uma análise do ensino jesuítico implementado no período colonial brasileiro e demonstrar que a estrutura escolar fundada pelos padres jesuítas no Brasil era adequada para o momento histórico vivenciado, levando-se em consideração quatro aspectos: os objetivos do Projeto Português para o Brasil; o Projeto Educacional Jesuítico; a própria estrutura social brasileira da época; e o modelo de homem necessário para a época colonial.

Os jesuítas, com seu projeto educacional, e os portugueses que vieram para a Colônia brasileira em busca de riquezas, tiveram papel fundamental na formação da estrutura social, administrativa e produtiva da sociedade que estava sendo formada.

Partindo do pressuposto de que o fenômeno educacional não é um fenômeno independente e autônomo da realidade social de determinado momento histórico, devemos analisar o projeto jesuítico levando-se em conta o desenvolvimento social e produtivo da época colonial. Assim, pode-se supor que o modelo educacional proposto pelos jesuítas, que pretendia formar um modelo 
de homem, baseado nos princípios escolásticos, era coerente com as necessidades e aspirações de uma sociedade em formação na primeira fase do período colonial brasileiro.

Para consecução dos objetivos do Projeto Português de colonização das terras brasileiras, a Coroa portuguesa contou com a colaboração da Companhia de Jesus. Segundo Leite (1965), Azevedo (1976) e Ribeiro (1998), a principal intenção do rei D. João III ${ }^{1}$ ao enviar os jesuítas para a Colônia brasileira - tal idéia e o conselho foram de Diogo de Gouveia - foi para converter o índio à fé católica por intermédio da catequese e do ensino de ler e escrever português.

A Ordem dos Jesuítas é produto de um interesse mútuo entre a Coroa de Portugal e o Papado. Ela é útil à Igreja e ao Estado emergente. Os dois pretendem expandir o mundo, defender as novas fronteiras, somar forças, integrar interesses leigos e cristãos, organizar o trabalho no Novo Mundo pela força da unidade lei-rei-fé. (RAYMUNDO, 1998, p. 43)

Os jesuítas tornaram-se uma poderosa e eficiente congregação religiosa, em parte em função de seus princípios fundamentais, que eram a busca da perfeição humana por intermédio da palavra de Deus e a vontade dos homens; a obediência absoluta e sem limites aos superiores; a disciplina severa e rígida; a hierarquia baseada na estrutura militar; e a valorização da aptidão pessoal de seus membros. Tiveram uma grande expansão nas primeiras décadas de sua formação, constatada pelo crescimento de seus membros, pois em 1856 contava com mil membros e em 1606 esse número cresceu para 13 mil.

A Ordem dos Jesuítas não foi, entretanto, criada só com fins educacionais; ademais, parece que no começo não figuravam esses entre os propósitos, que eram antes a confissão, a pregação e a catequização. Seu recurso principal eram os chamados "exercícios espirituais", que exerceram enorme influência anímica e religiosa ente os adultos. Todavia pouco a pouco a educação ocupou um dos lugares mais importantes, senão mais importante, entre as atividades da Companhia.

1 D. João III (1502-1557) nasceu na cidade de Lisboa em 6 de junho. Primeiro filho de D. Manuel I com a rainha D. Maria de Castela. Assumiu o trono de Portugal em 19 de dezembro de 1521, alguns dias após a morte de seu pai, e reinou durante 36 anos. Casou-se com D. Catarina, irmã do imperador Carlos V, em 1525, e veio a falecer em junho de 1557. Em seu reinado, procurou intensificar as atividades de política interna e ultramarina e, também, as relações diplomáticas com os Estados europeus. 
A Companhia, como se sabe, é composta de membros, que têm, a um tempo, caráter regular e secular; são membros de uma ordem religiosa com estatutos e autoridades próprias e do mesmo passo são sacerdotes ordenados que exercem todas as funções dos demais sacerdotes. Ao contrário das outras ordens religiosas, vivem no século, no mundo; e a Companhia tem caráter sumamente empreendedor e combativo. Sua mesma designação de Companhia já indica o caráter de milícia, assim como a organização, disciplina e espírito de obediência, tudo para a maior glória de Deus (Omnia ad Majorem Dei Gloriam ou, abreviadamente, A.M.D.G.). Dependem os membros de um Geral e, em cada nação, de um provincial, embora submetidos à autoridade do Papa. (LUZURIAGA, 1975, p. 118-119)

A Companhia de Jesus foi fundada em pleno desenrolar do movimento de reação da Igreja Católica contra a reforma protestante, podendo ser considerada um dos principais instrumentos da Contra-Reforma nessa luta. Seu objetivo era tentar sustar o grande avanço protestante da época, e para isso utilizou-se de duas estratégias: por meio da educação dos homens e dos índios; e por intermédio da ação missionária, procurando converter à fé católica os povos das regiões que estavam sendo colonizadas.

Para Azevedo (1976), a Companhia de Jesus tinha como princípio formar um exército de soldados da Igreja Católica capazes de combaterem a heresia e converter os pagãos, apresentando desse modo características de uma milícia. Para atingir seus objetivos, os jesuítas - soldados de Cristo -, deveriam passar por uma reciclagem intelectual e científica para combater os vícios e os pecados e purificá-los contra o mal. Seu papel na sociedade portuguesa da época foi fundamental, pois cabia a eles propiciar as condições necessárias para educar os grupos sociais menos favorecidos da população. Portanto, sua obra tornava-se uma atividade de caridade. Portanto, o ensino jesuítico, no início de suas atividades, não era um ensino para todos e sim para uma pequena parcela da população, pois destinava-se exclusivamente a ensinar os "ignorantes" a ler e escrever.

Serrão (1980) e Vasconcelos (1977) consideram que a história da Companhia de Jesus está circunstanciada de ambigüidades, pois

nenhuma instituição humana há sido julgada com mais parcialidade do que a dos jesuítas: para uns foram eles a idealização do poder católico, o tipo mais perfeito do ministro do Evangelho, numa palavra verdadeiros apóstolos, como em sua aparição, os denominou o povo; para outros simboliza o instituto de Loyola a falsificação da fé, o relaxamento das máximas da moral cristã, a corrupção da disciplina eclesiástica, quando exigiam-no os interesses de sua egoísta política. (VASCONCELOS, 1977, p. 40) 
Assim, pode-se supor que os jesuítas possuíam um projeto educacional, que, apesar de estar subordinado ao Projeto Português para o Brasil, tinha determinada autonomia, teve papel fundamental e acabou contribuindo para que o Governo português atingisse seus objetivos no processo de colonização e povoamento da colônia brasileira. Os jesuítas formularam seu Projeto Educacional, que denominaremos Projeto Educacional Jesuítico, sendo este o alicerce da nova estrutura social e educacional da Colônia brasileira.

\section{Os jesuítas e seu projeto educacional}

A Companhia de Jesus foi uma ordem religiosa da Igreja Católica, fundada na Europa em 1540 por Inácio de Loyola ${ }^{2}$. Era formada por padres designados de jesuítas, que tinham como missão catequizar e evangelizar as pessoas, pregando o nome de Jesus. Os princípios básicos dessa ordem estavam pautados em: 1) a busca da perfeição humana por meio da palavra de Deus e a vontade dos homens; 2) a obediência absoluta e sem limites aos superiores; 3) a disciplina severa e rígida; 4) a hierarquia baseada na estrutura militar; 5) a valorização da aptidão pessoal de seus membros. São esses princípios que eram rigorosamente aceitos e postos em prática por seus membros, que tornaram a Companhia de Jesus uma poderosa e eficiente congregação.

Com a descoberta pelos portugueses e espanhóis das terras da América, seu projeto foi ampliado e levado para as novas terras, a fim de pregar a palavra de Deus entre os índios. Pode-se supor que o Projeto Educacional Jesuíticos Jesuítas, apesar de estar subordinado ao Projeto Português para o Brasil, tinha determinada autonomia, e teve papel fundamental na medida em que contribuiu para que o Governo português atingisse seus objetivos no processo de colonização brasileiro, bem como se constituiu no alicerce da estrutura educacional da Colônia brasileira.

O Projeto Educacional Jesuítico não era apenas um projeto de catequização, mas sim um projeto bem mais amplo, um projeto de transformação social, pois tinha como função propor e implementar mudanças radicais na cultura indígena brasileira. Ou seja, era um projeto de transformação social, pois tinha

2 Inácio de Loyola (1491-1566) nasceu em Azpéitia, Espanha. De família fidalga, acabou por seguir a carreira militar, convertendo-se à vida religiosa somente após ser ferido em 1521 no cerco de Pamplona pelas tropas francesas. Estudou humanidades nas Universidades de Alcalá e Salamanca, Espanha, e teologia na Universidade de Paris. Em Roma, fundou a Companhia de Jesus, que o Papa Paulo III aprovou em 1540. 
como função propor e implementar alterações profundas na cultura indígena brasileira. Teixeira Soares (1961, p. 142) afirma que a Companhia de Jesus surgiu como "uma explosão de pensamento religioso transvertido ao campo das atividades práticas. Refazer o homem, infundir-lhe espírito novo, arquetipá-lo em finalidade sociais e religiosas, foi a ação da Ordem."

Ao analisarmos o Projeto Jesuítico para o Brasil Colônia, devemos ter em mente que o mesmo, apesar de ter atingido satisfatoriamente seus objetivos iniciais, foi sendo conquistado gradativamente, com muitas dificuldades e esforços de seus membros.

O trabalho de catequização e conversão do gentio ao cristianismo, motivo formal da vinda dos jesuítas para a Colônia brasileira, destinava-se à transformação do indígena em "homem civilizado", segundo os padrões culturais e sociais dos países europeus do século XVI, e à subseqüente formação de uma "nova sociedade". Essa preocupação com a transformação do indígena em homem civilizado justifica-se pela necessidade em incorporar o índio ao mundo burguês, à "nova relação social" e ao "novo modo de produção". Desse modo, havia uma preocupação em inculcar no índio o hábito do trabalho, pelo produtivo, em detrimento ao ócio e ao improdutivo.

Segundo Azevedo (1976), a atuação jesuítica na colônia brasileira pode ser dividida em duas fases distintas: a primeira fase, considerando-se o primeiro século de atuação dos padres jesuítas, foi a de adaptação e construção de seu trabalho de catequese e conversão do índio aos costumes dos brancos; já a segunda fase, o segundo século de atuação dos jesuítas, foi de grande desenvolvimento e extensão do sistema educacional implantado no primeiro período.

A exemplo de outros europeus (conquistadores e colonizadores), os padres jesuítas, num primeiro momento, tinham uma imagem do índio que o caracterizou como o "bom gentio", bem como o seu modo de viver e seus costumes eram motivo de admiração, visto serem considerados exóticos.

Já num segundo momento, os indígenas passam a ser encarados pelos padres jesuítas como um empecilho para a consecução de seus objetivos, pois, ao não se adaptarem às exigências do trabalho árduo, rotineiro e contínuo, destinado à acumulação e não mais apenas à sobrevivência, tornam-se insubordinados, abandonando, dessa maneira, as missões e retornando para suas aldeias.

O modelo ideal de homem, o homem puro, cristão e livre dos pecados do mundo burguês, que buscavam os padres jesuítas, poderia ser este homem inocente, encontrado em terras brasileiras. As Cartas Jesuíticas ${ }^{3}$ documento

As Cartas Jesuíticas são documentos apresentados sob a forma de cartas escritas pelos padres jesuítas e que tinham como objetivo fornecer um relato das atividades desenvolvidas pela Companhia nas terras descobertas. As cartas foram escritas, principalmente, pelos padres Manoel da Nóbrega, Azpicueta Navarro e José de Anchieta, entre 1549 e 1568. 
que relata as preocupações, as necessidades e as atividades realizadas pelos padres jesuítas. Juntamente com suas atividades de catequização, os jesuítas tentaram desenvolver no indígena a preocupação burguesa com o trabalho, com o produtivo.

O primeiro grupo de jesuítas chegou à Colônia brasileira em 1549, na mesma época em que desembarcou o Governador-Geral Tomé de Sousa. Eram chefiados pelo padre Manuel da Nóbrega, que se tornou o primeiro Provincial com a fundação da província jesuítica brasileira em 1553, permanecendo no cargo entre 1549-1559 e sendo substituído por Luís de Grã (1559-69).

O padre Manuel da Nóbrega e seus companheiros da Companhia de Jesus fundaram na Bahia, em agosto de 1549, a primeira "escola de ler e escrever" brasileira.

Portugal, que até então vivera imerso na atmosfera medieval e ocupado com as intermináveis guerras santas contra os invasores mouriscos e guerras defensivas contra os espanhóis, começava apenas a despertar para a nova cultura da Renascença. Sem tradições educativas, o seus sistema escolar começava a esboçar-se mui vagamente apenas.

$\mathrm{O}$ analfabetismo dominava não somente as massas populares e a pequena burguesia, mas se estendia até a alta nobreza e família real. Saber ler e escrever era privilégio de poucos, na maioria confinados à classe sacerdotal e à alta administração pública.

É bem verdade que os mosteiros e as catedrais eram quase que os únicos asilos das letras, tanto sagradas como profanas; mas sua atuação era modesta e restrita à satisfação de suas necessidades internas; não tinham a consciência de estar cumprindo uma missão social. (MATTOS, 1958, p. 37-38)

Ao contrário do que se poderia imaginar, mesmo na grande maioria dos países europeus da época não havia um sistema escolar modelo, visto que,

se o sistema escolar português de 1549 era, como acabamos de ver, ainda diminuto e embrionário, nem por isso diríamos que Portugal estava nesse ponto em grande atraso em relação à maior parte dos países da Europa. A situação era mais ou menos a mesma na Espanha, no sul da Itália, na Bélgica, Holanda, Inglaterra, Irlanda, Países Escandinavos, Polônia, Rússia e nos Balcans.

O ideal democrático de uma rede escolar para toda a massa da população ainda não começara a materializar-se, previsto apenas vagamente pelos devaneios utópicos de Thomas Morus e Campanella. 
Quanto a planos e tentativas de organização de um sistema escolar extensivo a toda a população, abrangendo todos os graus de instrução como o entendemos modernamente, apenas começavam a surgir por essa época as primeiras idéias com Luthero e Sturm na Alemanha (1536), Calvino em Genebra (1538), Santo Inácio de Loyola (1540) e o Concilio de Trento (1545), em função da tremenda luta religiosa que desde 1517 abalava a Europa. Esse sistema escolar em gestação seria, apenas, um recurso estratégico nessa luta e, como tal, começava a ser discutido e ensaiado na Alemanha, França, Suíça e norte da Itália. (MATTOS, 1958, p. 41-42)

Ao desembarcar no Brasil, o padre Manuel da Nóbrega faz a nomeação de seus ajudantes para algumas funções essenciais. Desse modo, com a nomeação e atribuição de funções aos demais padres jesuítas, é redigido o primeiro status ou catálogo da missão brasileira. A utilização de um método de ensino para conversão do índio ao catolicismo deve-se à seguinte questão: e, como iriam os padres jesuítas pregar a fé católica se não conseguiam se comunicar com os indígenas?

O plano de estudos organizado pelo padre Manuel da Nóbrega consistia em duas fases: na primeira fase, considerada como do ensinamento dos estudos elementares, era constituída pelo aprendizado de português, do ensinamento da doutrina cristã e da alfabetização. Para a segunda fase do processo de aprendizagem idealizado por Manuel da Nóbrega, o aluno teria a opção para escolher entre o ensino profissionalizante e o ensino médio, segundo suas aptidões e dotes intelectuais revelados durante o ensino elementar. Como prêmio para os alunos que de destacassem nos estudos da gramática latina, previa-se o envio em viagem de estudos aos grandes colégios de Coimbra ou da Espanha.

Uma das estratégias adotadas por Manuel da Nóbrega na conversão dos gentios foi a construção de aldeias de catequização, que se situavam próximas das vilas e cidades portuguesas. Essas aldeias eram habitadas pelos padres jesuítas e pelos índios a serem convertidos e destinavam-se a atingir três objetivos:

- objetivo doutrinário - que visava ensinar a religião e a prática cristã aos índios;

- objetivo econômico - visava a instituir o hábito do trabalho como princípio fundamental na formação da sociedade brasileira;

- objetivo político - visava a utilizar os índios convertidos contra os ataques dos índios selvagens e, também, dos inimigos externos. 
Em 1551 desembarca no Brasil o segundo grupo de padres jesuítas oriundos de Lisboa, e juntamente com os padres vem um grupo de vinte meninos órfãos de Lisboa. Esses meninos já haviam sido orientados e treinados para desempenharem suas funções, auxiliar os jesuítas em sua obra de evangelização. Assim, logo que desembarcaram, foram distribuídos e enviados para os colégios jesuítas existentes nas terras brasileiras. Nesse mesmo ano, a escola da Bahia foi transformada em Colégio dos Meninos de Jesus ${ }^{4}$.

O padre Manuel da Nóbrega, conhecido como o grande defensor dos índios ${ }^{5}$, em suas décadas à frente dos jesuítas no Brasil, teve papel ativo no processo de colonização e catequização dos índios. Coube a ele colaborar ativamente na fundação da aldeia de Piratininga (1553), que tornar-se posteriormente a cidade de São Paulo, no Colégio de São Paulo (1554) e na cidade do Rio de Janeiro (1565). Entretanto, a maior contribuição ocorreu na área educacional, sendo sua contribuição ainda maior, pois sob seu comando foram fundadas cinco escolas de instrução elementar (em Porto Seguro, Ilhéus, Espírito Santo, São Vicente e São Paulo de Piratininga) e três colégios (no Rio de Janeiro, Pernambuco e Bahia).

A fundação da aldeia de Piratininga representa um fato importante das atividades jesuíticas na Colônia brasileira, pois sua localização privilegiada o capacita para tornar-se muito mais que um núcleo de catequese, mas um centro irradiador de povoamento. A fundação de Piratininga data de 25 de janeiro de 1554 e somente foi possível graças à desobediência do padre Manuel da Nóbrega ao Regimento de Tomé de Sousa, que restringia a colonização apenas ao litoral da colônia, proibindo assim a colonização do interior.

Em 13 de julho de 1553 chega à Bahia um novo grupo de padre jesuítas, o terceiro grupo a vir para o Brasil, composto de seis padres sob o comando de Luiz de Grã.

Vicente Rodrigues (1528-1600), conhecido por Vicente Rijo, nasceu em Sacavém, Portugal, e era irmão do então Ministro do Colégio das Artes de

4 O Colégio de Jesus da Bahia foi fundado em fins do ano de 1549. Com instalações e acomodações pequenas, que lhe impunham uma limitação no número de alunos, nunca contou com mais de 25 alunos internos (entre órfãos, índios e mamelucos). Também freqüentavam as aulas de ler e escrever alguns alunos externos (em sua maioria filhos de colonos portugueses). Entre sua fundação e 1556, contou com quatro mestres: Vicente Rodrigues - ministrou aulas entre abril de 1549 e julho de 1550; Salvador Rodrigues - atuou entre julho de 1550 e julho de 1553; Antonio Blasques - exerceu as atividades docentes entre julho e novembro de 1553; e João Gonçalves - que exerceu a atividade docente entre novembro de 1553 e 1556.

5 A liberdade dos indígenas sempre foi defendida pelos padres da Companhia de Jesus, apesar de não se oporem formalmente à escravatura, em virtude sua situação frente à Coroa portuguesa. 
Coimbra, padre Jorge Rijo. Ingressou em Coimbra aos 17 anos na Companhia de Jesus, onde fez seu noviciado.

Aos 21 anos de idade, já na Bahia, foi incumbido, pelo padre Manuel da Nóbrega, de catequizar e ensinar a ler e escrever os meninos indígenas, tornando-se, desse modo, o primeiro professor a ministrar aulas na primeira escola brasileira, o Colégio da Bahia. Após quatorze anos de belo trabalho e bons resultados, o padre Vicente Rijo foi transferido por motivos de saúde para Porto Seguro.

Em 1553 o padre Manuel da Nóbrega ${ }^{6}$ retirou-se para as capitanias do Sul e nomeou Vicente Rijo como superior interino do Colégio da Bahia. Em 1554 entregou provisoriamente a regência do Colégio da Bahia aos padres António Blasques e José de Anchieta e embarcou juntamente com onze jesuítas para São Vicente, com o objetivo de fundarem o novo colégio de São Paulo de Piratininga. Após sete anos de trabalho de catequização no Colégio de São Paulo de Piratininga, Vicente Rijo foi promovido a superior, onde ficou até 1753, quando foi transferido para o Colégio da Bahia.

Ainda em 1553, o padre Manuel da Nóbrega realizou visita ao recolhimento de São Vicente ${ }^{7}$, trazendo quatro órfãos de Lisboa para auxiliarem no trabalho de catequização. Em fevereiro desse mesmo ano, o recolhimento passou a denominar-se Colégio dos Meninos de Jesus de São Vicente. O colégio oferecia aos seus alunos internos e externos (contava com aproximadamente cem alunos matriculados), além do ensino de grau primário e secundário, o ensino artístico.

Em síntese, o Colégio dos Meninos de Jesus de São Vicente foi a instituição educacional que melhor se desenvolveu nesse fase pioneira da educação no Brasil e serviu para pôr em evidência as ricas possibilidades do primitivo plano educacional esboçado por D. João III no Regimento de 1548. (MATTOS, 1958, p. 75)

6 Antes de falecer em 1600, com 62 anos de idade, ainda desempenhou por mais de quinze anos no Colégio do Rio de Janeiro as mesmas funções de Administrador da Igreja e Diretor Espiritual da comunidade. Foram 41 anos de dedicação e trabalhos em prol da catequização e evangelização dos indígenas brasileiros, que lhe valeram o título de Primeiro Mestre-Escola do Brasil.

7 O recolhimento de São Vicente foi fundado em 1550 pelo padre Leonardo Nunes e destinava-se, inicialmente, à catequese. 
Os colégios da Bahia e de São Vicente foram os mais prósperos da Companhia de Jesus. Os jesuítas também fundaram colégios no Espírito Santo (padre Afonso Braz) e em Porto Seguro (padre Azpicuelta Navarro).

O apoio e a proteção na metrópole para que o padre Manuel da Nóbrega desempenhasse suas atividades na Colônia brasileira eram proporcionados pelo padre Mestre Simão Rodrigues ${ }^{8}$.

Em 1552, o padre Mestre Simão Rodrigues, após desentendimentos com Inácio de Loyola, foi substituído no cargo de Provincial de Portugal pelo padre Diogo Mirão e enviado ao reino de Aragão. Este fato implicou no abandono de alguns padres da Companhia de Jesus e a cessação do apoio do Provincial de Portugal à política dos recolhimentos do padre Manuel da Nóbrega no Brasil.

Além da crise interna no seio da própria Companhia de Jesus, resultante dos desentendimentos havidos entre Santo Inácio de Loyola e Simão Rodrigues, sob cuja inspiração se concebera e se incentivara a política dos recolhimentos e das confrarias dos meninos, outra razão havia, mais profunda e decisiva, determinando esta mudança de orientação. Era que as novas Constituições da Companhia de Jesus proibiam a manutenção de internatos para educandos leigos, que não fossem candidatos com vocação religiosa para ingressar nas fileiras militantes da Companhia. (MATTOS, 1958, p. 119)

O novo Provincial da Companhia de Jesus em Portugal, o padre Diogo Mirão, com pensamento contrário ao de seu antecessor, logo impôs uma nova política.

Além disso, o exemplar desprendimento apostólico, implícito na política de fundar confrarias de escolares com autonomia financeira e administrativa sobre bens temporais, não se enquadrava com a nova orientação dada por Mirão à Companhia na metrópole. (MATTOS, 1958, p. 105)

8 Padre Mestre Simão Rodrigues foi o fundador e primeiro Provincial da Companhia de Jesus em Portugal e confessor predileto de D. João III, motivo pelo qual tinha apoio do governante. Em 1553 voltou para Portugal, mas foi proibido de ficar por Inácio de Loyola, sendo exilado em Roma durante vinte anos. Apenas conseguiu retornar para Portugal em 1579, quando veio a falecer. 
Os três principais defensores da política educacional de Nóbrega foram $\mathrm{D}$. João III, o Mestre Simão Rodrigues e Tomé de Sousa. Ao mesmo tempo em que perdeu seu apoio, adquiriu quatro grandes adversários: o padre Diogo Mirão, Luiz de Grão, o Bispo Dom Pedro Sardinha e D. Duarte da Costa.

Em 1556 foi promulgada no Brasil a nova constituição da Companhia de Jesus, fato que provocou mais uma derrota para o padre Manuel da Nóbrega em sua luta contra a nova política provincial de Portugal. Pois, segundo as regulamentações da nova constituição foi proibida a manutenção de internatos para educandos leigos, que não fossem candidatos da Companhia de Jesus.

\section{O método educacional jesuítico - o Ratio Studiorum}

O Ratio Atque Institutio Studiorum Societatis Jesu' ${ }^{9}$, mais conhecido pela denominação de Ratio Studiorum, foi o método de ensino, que estabelecia o currículo, a orientação e a administração do sistema educacional a ser seguido, instituído por Inácio de Loyola para direcionar todas as ações educacionais dos padres jesuítas em suas atividades educacionais, tanto na colônia quanto na metrópole, ou seja, em qualquer localidade onde os jesuítas desempenhassem suas atividades.

O Ratio Studiorum não era um tratado sistematizado de pedagogia, mas sim uma coletânea de regras e prescrições práticas e minuciosas a serem seguidas pelos padres jesuítas em suas aulas. Portanto, era um manual prático e sistematizado que apresentava ao professor a metodologia de ensino a ser utilizada em suas aulas.

O método educacional jesuítico foi fortemente influenciado pela orientação filosófica das teorias de Aristóteles e de São Tomás de Aquino, pelo Movimento da Renascença ${ }^{10}$ e por extensão, pela cultura européia. Apresentava como peculiaridades a centralização e o autoritarismo da metodologia, a orientação universalista, a formação humanista e literária e a utilização da música.

O Ratio Studiorum apresentava três opções de cursos: o curso secundário, que correspondia ao curso secundário, e dois cursos superiores, o curso de teologia e o curso de filosofia. Os cursos eram constituídos por disciplinas,

9 O Ratio Studiorum foi publicado originariamente em 1599 pelo padre Geraldo Cláudio Aquaviva e visava à formação do homem cristão, de acordo com a fé e a cultura cristã.

10 O período denominado de Renascimento foi um período compreendido entre os séculos XV e XVI, em que ocorreram profundas transformações na sociedade européia, caracterizado, também, pelo questionamento dos métodos de ensino da escolástica. 
também denominadas de classes, que caracterizavam-se por graus de progressos que correspondiam ao período de um ano. Assim, sua proposta curricular dividia-se em duas partes distintas: os "estudos inferiores", conhecidos por ensino secundário; e os "estudos superiores".

Os cursos secundários com duração de cinco anos, que na maioria das vezes prorrogavam-se por seis anos, destinavam-se à formação eminentemente literária e humanista, pois o ensino ministrado era fundamentalmente literário e clássico.

Portanto, o objetivo do curso de humanidades era

a arte acabada da composição, oral e escrita. O aluno deve desenvolver todas as suas faculdades, postas em exercício pelo homem que se exprime e adquirir a arte de vazar esta manifestação de si mesmo nos moldes de uma expressão perfeita. As classes de gramática asseguravam-lhe uma expressão clara e exata, a de humanidades, uma expressão rica e elegante, a de retórica mestria perfeita na expressão poderosa e convincente "ad perfectam aloquentiam informat”. (LEONEL FRANCA, 1952, p. 49)

Esse curso de humanidades foi o que mais se propagou e difundiu na Colônia, podendo ser considerado o alicerce da estrutura educacional jesuítica.

Já os cursos superiores eram integrados pelos cursos de filosofia e ciências, também denominado de curso de "artes". Tinham duração de três anos e eram direcionados para a formação do filósofo, pois as disciplinas que compunham os estudos eram a lógica, a metafísica, a matemática, a ética e as ciências físicas e naturais.

Para Leonel Franca (1952), os estudos universitários organizados pelo Ratio Studiorum visavam à formação profissional do homem, enquanto que os cursos secundários tinham a finalidade de formar o humanista, o homem para viver em sociedade.

No Brasil os jesuítas elaboraram, tendo como base o Ratio Studiorum, um plano de estudos de forma:

(...) diversificada, com o objetivo de atender à diversidade de interesses e de capacidades. Começando pelo aprendizado do português, incluía o ensino da doutrina cristã, a escola de ler e escrever. Daí em diante, continua, em caráter opcional, o ensino de canto orfeônico e de música instrumental, e uma bifurcação tendo em um dos lados, o aprendizado profissional e agrícola e, de outro, aula de gramática e viagem de estudos à Europa. (RIBEIRO, 1998, p. 21-22) 
Logo, pode-se deduzir que o plano de estudos - o Ratio Studiorum utilizado no Brasil, inicialmente pelo padre Manuel da Nóbrega, foi adaptado ${ }^{11}$ para atender as necessidades, especificidades e diversidades encontradas na Colônia.

\section{Considerações finais}

A atuação jesuítica na Colônia pode ser compreendida em duas fases distintas: a primeira corresponde ao período de adaptação e construção de seu trabalho de catequese e conversão do índio aos costumes dos brancos. Já a segunda fase, que corresponde ao segundo século de sua atuação, foi um período de grande desenvolvimento do sistema educacional implantado no primeiro período, ou seja, foi a fase de consolidação de seu projeto educacional.

Inicialmente os padres jesuítas dedicaram-se à catequização e à conversão do gentio à fé católica, mas com o passar dos anos começaram a se dedicar, também, ao ensino dos filhos dos colonos e demais membros da Colônia, atingindo num último estágio até a formação da burguesia urbana, constituída, principalmente, pelos filhos dos donos de engenho. Esses jovens, que após o término de seus estudos no Brasil partem para estudarem na Universidade de Coimbra, vão impulsionar muito mais tarde o espírito nacionalista. Por meio de seu ensino e sua metodologia, os jesuítas exerceram grande influência sobre a embrionária sociedade brasileira, constituída pelos filhos da classe burguesa.

As principais críticas efetuadas pelos adversários políticos dos jesuítas no Reino ao método pedagógico são:

a educação da mocidade reinol e colonial, monopolizada pelos padres, orientava-se, sem dúvida, para a uniformidade intelectual; os quadros do seu ensino, dogmático e abstrato, não apresentavam plasticidade para se ajustarem às necessidades novas: os métodos, autoritários e conservadores até a rotina; e, além de não incluir o ensino das ciências, esse plano de estudos, excessivamente literários e retóricos, não abria lugar para as línguas modernas, conservando nas elites uma tal ignorância sobre essas línguas que de maravilha se encontraria, na colônia, um brasileiro que soubesse francês. (AZEVEDO, 1976, p. 48)

11 Neves (1993) acredita que os jesuítas, ao organizarem o ensino a ser aplicado na conversão dos índios, puderam moldar as leis e práticas impostas pela ordem, mesmo porque o Ratio Studiorum estava em fase de elaboração, apenas tendo sido aprovado em 1759. 
As causas da expulsão dos jesuítas do Brasil podem ser categorizadas: políticas e ideológicas - a Companhia de Jesus tornara-se um empecilho aos interesses do Estado Moderno, além do que era detentora de grande poder econômico, cobiçado pela Coroa portuguesa; e educacional - as transformações sociais advindas do movimento Iluminista e dos princípios liberais requeriam a formação de um novo homem, o homem burguês, o comerciante, e não mais o homem cristão.

Pode-se supor que a expulsão da Companhia de Jesus e a destruição de sua organização educacional são duas ordens:

- política - os jesuítas representavam um empecilho aos interesses do Estado Moderno, além de ser detentora de grande poder econômico, cobiçado pelo Estado;

- educacional - a necessidade da educação formar um novo homem - o comerciante e o homem burguês, e não mais o homem cristão -, pois os princípios liberais e o movimento Iluminista trazem consigo novos ideais e uma nova filosofia de vida.

Assim, concordamos com Teixeira Soares (1961), quando afirma que os jesuítas pretendiam formar o modelo de homem cristão, diferentemente do homem burguês que estava sendo formado na Europa. Contudo, discordamos do pesquisador na medida em que o mesmo afirma que os jesuítas pretendiam formar um "novo homem", pois na realidade os padres jesuítas estavam lutando para manter vivo o "atual modelo de homem" - o homem cristão - que estava sendo substituído pelo modelo de homem burguês.

A análise da expulsão da Companhia de Jesus deve ser compreendida enquanto um processo mais amplo, e que envolve questões de cunho político, ideológico e econômico. E, portanto, que não foi específico de Portugal, pois foi observado em outros países da Europa, como por exemplo, na Espanha.

(...) deve ser considerada a hipóteses de que, para além de todas as motivações de natureza ideológica de fundo mais ou menos iluminístico, o fenômeno da expulsão dos jesuítas da Península Ibérica se liga fundamentalmente a uma dada conjuntura imperial quer de Portugal quer de Espanha. É que no Brasil as minas de ouro tendiam para a exaustão, o que tornava necessário rever e recondicionar uma nova política geral para com a grande colônia sul-americana, sem a qual Portugal não fazia sentido no mundo de então. Ora, o tradicional papel dos jesuítas no Brasil - a sua força ideológica e até econômica - impedia ou dificultava esse recondicionamento da política luso-brasileira. (SERRÃO, 1984, p. 356) 
Esse processo, denominado de antijesuitismo, representava uma atitude presente em muitos países europeus, não sendo exclusividade de Portugal. Nesse sentido, os jesuítas representavam um obstáculo e fonte de resistência às tentativas de implantação da nova filosofia iluminista que se difundia rapidamente por toda a Europa.

Para Teixeira Soares (1961), as reformas elaboradas pelo Marquês de Pombal, em seu mandato como Ministro, visavam a transformar e adaptar a sociedade portuguesa aos movimentos sociais, econômicos e políticos que estavam ocorrendo na Europa do século XVIII.

Contudo, é preciso atentar-se para uma peculiaridade a ser destacada nesse processo de expulsão dos jesuítas e de formulação das reformas de Pombal, que tem início nesse momento histórico e que acompanhará a educação brasileira ao longo dos anos: as reformas educacionais brasileiras apresentam como característica marcante a total destruição e substituição das antigas propostas pelas novas.

A importância do trabalho dos jesuítas para a vida da Colônia brasileira e, principalmente, para a educação brasileira é apontada por Leite (1940), Teixeira Soares (1961), Veríssimo (1980), Serrão (1980), Avellar (1983), Almeida (2000), Holanda (1989), Ribeiro (1998) e Azevedo (1976, p. 9). Assim, a

vinda dos padres jesuítas, em 1549, não só marca o início da história da educação no Brasil, mas inaugura a primeira fase, a mais longa dessa história, e, certamente a mais importante pelo vulto da obra realizada e sobretudo pelas conseqüências que dela resultaram para nossa cultura e civilização. (RIBEIRO, 1998, p. 28)

Ribeiro, complementa destacando a importância social dos jesuítas para a sociedade colonial, pois

se transformaram na única força capaz de influir no domínio do senhor do engenho. Isto foi conseguido não só através dos colégios, como dos confessionário, do teatro e, particularmente, pelo terceiro filho, que deveria seguir a vida religiosa. Já para Leite $(1965,213)$, mais vasta que a artística - e em muitos aspectos mais valiosa - é a herança cultural, científica e literária dos jesuítas do Brasil, a começar pelo que se refere aos Índios. (RIBEIRO, 1998, p. 28) 
Para Azevedo (1976), Almeida (2000) e Ribeiro (1998), a eficácia do ensino jesuítico somente pôde ser concretizada após um longo e lento processo de adaptação às realidades sociais da Colônia e do povo brasileiro. E Leite (1965, p. 54) complementa ainda, afirmando "que essa eficácia assentou-se sobretudo em elementos de ordem moral (persuasão, emulação, repreensão), mas sobretudo sem excluir os de ordem física".

Segundo Azevedo (1976), a atuação jesuítica na Colônia brasileira pode ser dividia em duas fases distintas: na primeira fase, considerando-se o primeiro século de atuação dos padres jesuítas, foi a de adaptação e construção de seu trabalho de catequese e conversão do índio aos costumes dos brancos; já a segunda fase, o segundo século de atuação dos jesuítas, foi de grande desenvolvimento e extensão do sistema educacional implantado no primeiro período.

Azevedo, justifica a opção pelo ensino de atividades literárias e pelo ensino de humanidades em detrimento ao ensino técnico e profissionalizante, pois

a exploração de suas fazendas, de que vendiam os produtos; o aproveitamento do trabalho escravo ou do índio e a própria formação profissional, sob a pressão das circunstâncias, de um corpo de mestres e oficiais, não eram senão meros instrumentos, meios para a realização dos fins religiosos e educativos a que se propunham os padres jesuítas. (AZEVEDO, 1976, p. 41)

Portanto, era coerente a proposta educacional jesuítica, pois vinha ao encontro de seus objetivos principais na Colônia, a conversão do índio à fé cristã e o trabalho educativo.

Posteriormente, o ensino jesuítico dedicou-se, também, à formação da burguesia urbana. Assim, para Azevedo,

uma das conseqüências, porém, certamente a mais larga e a mais importante, dessa cultura urbanizadora que se desenvolveu pela ação pedagógica dos jesuítas, foi a unidade espiritual que ela contribuiu notavelmente para estabelecer, fornecendo uma base ideológica, lingüística, religiosa e cultural à unidade e à defesa nacionais. (AZEVEDO, 1976, p. 42) 
Azevedo, conclui, afirmando que foi,

de fato, em grande parte pela influência dos padres que se preparou a base da unidade nacional na tríplice unidade de língua, de religião e de cultura, em todo o território. Nenhum elemento intelectual foi mais poderoso do que o ensino jesuítico, na defesa e conservação da língua culta. (AZEVEDO, 1976, p. 43)

Para Ribeiro (1998), não há como compreender a organização escolar na Colônia brasileira senão a implantada e vinculada à política colonizadora da metrópole. E destaca que

o importante a ressaltar é que a formação intelectual oferecida pelos jesuítas, e, portanto, a formação da elite nacional, será marcada por uma intensa "rigidez" na maneira de pensar e, conseqüentemente, de interpretar a realidade. (RIBEIRO, 1998, p. 25)

Por intermédio de seu ensino e sua metodologia, os jesuítas exerceram grande influência em todas as camadas da sociedade brasileira ainda em formação.

Como conclui Leite,

para se compreender bem o facto, tenha-se presente que a Companhia de Jesus nunca existiu como corporação isolada. A sua grande obra no Brasil, como ter personalidade própria, pertence à Igreja, como instituição que era dela, pertence à Portugal, como instrumento seu, nacional, de cultura e cristianização ultramarina. (LEITE, 1965, p. 232)

Portanto, e levando-se em conta as dificuldades, seus objetivos, as dimensões geográficas do Brasil, as estruturas materiais, físicas e financeiras disponíveis e sua relativa autonomia, os números da obra jesuítica impressionam pela grandeza, pois foram fundadas 36 missões; escolas de ler e escrever em quase todas as povoações e aldeias; 25 residências dos jesuítas; 18 estabelecimentos de ensino secundário, entre colégios e seminários, nos principais pontos do Brasil, entre eles: Bahia, São 
Vicente, Rio de Janeiro, Olinda, Espírito Santo, São Luís, Ilhéus, Recife, Santos, Porto Seguro, Paranaguá, Alcântara, Vigia, Pará, Colônia do Sacramento, Florianópolis e Paraíba.

A Companhia de Jesus teve suas atividades suspensas na Colônia brasileira a partir de 1759, com o Decreto-lei de 3 de setembro de 1759 promulgado pelo Rei D. José $\mathrm{I}^{12}$. Com a promulgação da lei, o Ministro de Estado, Marquês de Pombal, exilava de Portugal e da Colônia brasileira a Companhia de Jesus, confiscando para a Coroa portuguesa todos os seus bens materiais e financeiros. Quando da assinatura do decreto pelo Marquês de Pombal, havia no Brasil 670 membros da Companhia de Jesus, incluindo noviços e estudantes, sendo repatriados para Portugal 417. Permaneceram no Brasil 253 membros, entre aqueles que ainda não haviam recebido ordens ou os noviços que foram induzidos a deixarem a ordem religiosa.

Para Teixeira Soares (1961), Carvalho (1978), Ribeiro (1998), Cardoso (1990), Serrão (1980 e 1982), Avellar (1983), Holanda (1993) e Cruz (1984), as reformas elaboradas e implementadas ou não pelo Marquês de Pombal, em seu mandato como Ministro, visavam a transformação e adaptação da sociedade portuguesa aos movimentos sociais, culturais, econômicos e políticas que estavam a ocorrer na Europa do século XVIII.

Contudo, é preciso atentar-se para uma peculiaridade a ser destacada nesse processo de expulsão dos jesuítas e de implantação das reformas de Pombal, que tem início nesse momento histórico e que acompanhará a educação brasileira ao longo dos anos: as reformas educacionais brasileiras apresentam como característica marcante a total destruição e substituição das antigas propostas pelas novas. Assim, a reforma educacional do Marquês de Pombal confirma nossa hipótese - as reformas educacionais propostas na organização escolar brasileira utilizam-se da destruição e negação do que estava posto e a introdução de novas propostas, não havendo assim uma continuidade nas políticas educacionais.

Conforme afirmam Veríssimo (1980), Teixeira Soares (1961), Azevedo (1976), Serrão (1982), Almeida (2000), Holanda (1989) e Ribeiro (1998), os jesuítas foram os responsáveis pela formação da elite nacional. Pois, do período compreendido entre sua chegada em 1549 até sua expulsão em 1759, foram os responsáveis pelo ensino formal dos habitantes do Brasil, inclusive dos jovens que se preparavam para ingressar em cursos superiores na Universidade de Coimbra ${ }^{13}$.

12 D. José I (1714-1777) nasceu em 6 de junho. Filho e sucessor de D. João V, casou-se em 1729 com D. Mariana Vitoria e teve quatro filhas (D. Maria I, D. Maria Ana, D. Maria Francisca Dorotéia e D. Maria Francisca Benedita). Teve grande colaboração e influência em seu governo do Marquês de Pombal.

13 A Universidade de Coimbra, localizada em Portugal, foi a responsável pelo ensino superior de grande parte da elite política e intelectual brasileira nos séculos XVI, XVII e XVIII. 
Portanto, para Leite (1965), Teixeira Soares (1961), Almeida (2000), Ribeiro (1998) e Azevedo (1976), os padres jesuítas podem ser considerados os primeiros e únicos educadores do Brasil colonial. E complementa, ainda, Azevedo (1976, p. 36-37):

educadores, por vocação, mestres notáveis a todos os respeitos, eles puderam exercer na colônia, favorecidos por circunstâncias excepcionais, um verdadeiro monopólio do ensino, a que não faltava, para caracterizá-lo, o apoio oficial que thes deu o governo da Metrópole, amparando-os, na sua missão civilizadora e pacífica, com largas doações de terras e aplicações de rendimentos reais dotação de seus colégios.

Contudo, e como nos lembram Azevedo (1976), Serrão (1982) e Holanda (1989), a Companhia de Jesus não foi a única ordem religiosa que atuou na Colônia brasileira, mas foi sim aquela que mais destaque teve e a que primeiro desembarcou. Os membros das demais ordens, como os franciscanos, os carmelitas e os beneditinos, somente se instalaram e iniciaram seu trabalho por volta de 1580 , e, diferentemente dos jesuítas, não tinham na função educadora sua principal atividade.

Assim, pode-se supor que os jesuítas possuíam um projeto educacional, que, apesar de estar subordinado ao Projeto Português para o Brasil, tinha determinada autonomia, e teve papel fundamental e acabou contribuindo para que o Governo português atingisse seus objetivos no processo de colonização e povoamento da Colônia brasileira.

\section{REFERÊNCIAS}

ALMEIDA, José Ricardo Pires de. Instrução pública no Brasil (1500-1889): história e legislação. 2. ed. São Paulo: EDUC/INEP/MEC, 2000.

AVELLAR, Hélio de Alcântara. História administrativa do Brasil: a administração pombalina. 2. ed. Brasília: FUNCEP/Editora da UnB, 1983.

AZEVEDO, Fernando de. A cultura brasileira. 5. ed. São Paulo: Melhoramentos/INL, 1976. Parte 3: A transmissão da cultura. 
CARDOSO, Ciro Flamarion Santana. A crise do colonialismo luso na América Portuguesa: 1750/1822. In: LINHARES, Maria Yedda L. (Org.) História geral do Brasil. 6. ed. Rio de Janeiro: Campus, 1990.

CARVALHO, Laerte Ramos de. As reformas pombalinas da instrução pública. São Paulo: Saraiva/Edusp, 1978.

HOLANDA, Sérgio Buarque de. História geral da civilização brasileira: a época colonial. 8. ed. Rio de Janeiro: Bertrand Brasil, 1989. v. 1.

HOLANDA, Sérgio Buarque de. História geral da civilização brasileira: o Brasil monárquico. Rio de Janeiro: Bertrand Brasil, 1993. v. 1.

LEITE, Serafim. Suma história da Companhia de Jesus no Brasil (assistência de Portugal): 1549-1760. Lisboa: Junta de Investigação Ultramar, 1965.

LEONEL FRANCA, S. J. O método pedagógico dos jesuitas: o Ratio Studiorum. Rio de Janeiro: Agir, 1952.

LUZURIAGA, Lorenzo. História da educação e da pedagogia. 7. ed. São Paulo: Editora Nacional, 1975.

MATTOS, Luiz Alves de. Primórdios da educação no Brasil: o período heróico (15491570). Rio de Janeiro: Aurora, 1958.

NEVES, Fátima Maria. Educação jesuítica no Brasil-colônia: a coerência da forma e do conteúdo. 1993. 190 p. Dissertação (Mestrado). Universidade Metodista de Piracicaba.

RAYMUNDO, Gislene Miotto Catolino. Os princípios da modernidade nas práticas educativas dos jesuítas. 1998. 143 p. Dissertação (Mestrado). Universidade Estadual de Maringá.

RIBEIRO, Maria Luisa Santos. História da educação brasileira: a organização escolar. 15. ed. Campinas: Autores Associados, 1998.

SERRÃO, Joaquim Veríssimo. História de Portugal. 3. ed. Lisboa: Verbo, 1980. v. 2: A formação do Estado Moderno (1415-1495).

SERRÃO, Joaquim Veríssimo. História de Portugal. Lisboa: Verbo, 1982. v. 6: O despotismo iluminado (1750-1807).

TEIXEIRA SOARES, Álvaro. O Marquês de Pombal. Brasília: Editora da UnB, 1961.

VASCONCELOS, Simão de. Crônica da Companhia de Jesus. 3. ed. Petrópolis: Vozes/ INL/MEC, 1977. v. 1. 